\title{
Polski wojak Szwejk. O powieści Sól ziemi Józefa Wittlina ${ }^{1}$
}

Tłum. i oprac. Monika Anna Noga

\section{The Polish Soldier Svejk. On Józef Wittlin's Novel Sól ziemi [Salt of the Earth]}

Wakacje, choć wydawały się tak długie, to jednak dobiegły końca. Otoczcie serce moje, powracam w krąg drogi ${ }^{2}$. Życie, szczególnie to polityczne, jest bardzo rozedrgane; mało jest zakątków na świecie, gdzie nie dzieje się nic takiego, co by kogoś nie złościło lub nie zasmucało. Dawniej świat był rozległy i piękny, „w jakiejś Turcyi”3 oznaczało coś, co nikogo nie obchodziło. Dzisiaj już Nanking i Jokohama ${ }^{4}$ wywołują u niektórych bicie serca. Kochane postępy.

Ponieważ nastała jesień, opadają liście i pojawiły się pierwsze książki. (Są publikowane we wszystkich krajach, dla setek tysięcy, duch nie odpoczywa,

1 Tekst jest tłumaczeniem artykułu: A. Döblin, Ein polnischer Soldat Schweyk. Zu Joseph Wittlins Roman „Das Salz der Erde”, „Pariser Tageszeitung” 1936, nr 139. Wszystkie przypisy pochodzą od tłumaczki.

2 Parafraza cytatu z Fausta: „Die Träne quillt, die Strasse hat mich wieder” - „Die Träne quillt, die Erde hat mich wieder”. J.W. Goethe, Dzieta wybrane. Faust, cz. 1, tłum. F. Konopka, wyb. i wstęp S.H. Kaszyński, Warszawa 1983, s. 201 (wers 784, słowa Fausta: „Kręci się łza, znów ziemi przywrócony!").

${ }^{3}$ Cytat także pochodzi z Fausta, to słowa innego mieszczanina:

Nie ma to, kumie, jak świąteczną porą

O bitwach gwarzyć i wojennym krzyku,

Że tam gdzieś w jakiejś Turcyi daleko

Narody czubią się i za łby biorą.

Przy oknie stoisz sobie ze szklaneczką,

Patrzysz, jak rzeką w dół płyną okręty,

Wieczorem wesół wracasz do domeczku

I błogosławisz czas i pokój święty.

Tamże, s. 204.

${ }^{4}$ Chodzi najprawdopodobniej o masakrę nankińską w 1937 roku; w tym roku rozpoczęła się też tak zwana druga wojna chińsko-japońska, trwająca do roku 1945. 
ale na razie widać tylko, że Nanking i Jokohama niepokojąco się przybliżaja). Niedawno słuchałem w radio, w jednej z rozgłośni niemieckiej Rzeszy, „Godziny o książkach"s. Padły prawie całkowicie nieznane nazwiska, w zasadzie byłoby to zaleta, ale tytuły brzmiały bardzo znajomo, dopasowane do okropnego niecywilizowanego głosu spikera, i wyszczekiwały: „skwapliwośc”, „rzeczowość”, „tresura”. Jak mogła taka „literatura” dojść do głosu! Zawsze tak było - cóż, wszystko zalewają bizantyjskie fałszywe bazgroły.

Holenderskie wydawnictwa emigracyjne nie wydają w tym roku zbyt wielu książek. Czy winni są pisarze (ale przecież na emigracji pisze się dużo), czy wydawnictwa, którym doskwierają zbyt małe rynki zbytu? Wydawnictwo Querido $^{6}$ w Amsterdamie publikuje powieść Mefisto Klausa Manna ${ }^{7}$, drukowaną w „Pariser Tageszeitung”. Inaczej sprawa ma się bliżej nowego roku. Wydawnictwo Allert de Lange ${ }^{9}$ zapowiada wydanie powieści Spowiedź mordercy Josepha Rotha ${ }^{10}$ i Annerl Maxa Broda ${ }^{11}$ (w zasadzie ten prażanin nie jest emigrantem, ale po tym widać, jak daleko dziś pod względem kulturalno-politycznym sięga pojęcie „emigracja”).

Ale dzisiaj będzie tu mowa tylko o jednej książce, która ukazała się właśnie u Langego w Amsterdamie i zasługuje na wnikliwą uwagę i lekturę. Sól ziemi ${ }^{12}$ Józefa Wittlina to powieść przełożona z języka polskiego, pierwsza z zaplanowanych części trylogii Powieści o cierpliwym piechurze ${ }^{13}$. Następnie mają się ukazać Zdrowa śmierć i Dziura w niebie. Książki z tak obiecującymi tytułami są możliwe w Polsce, a Sól ziemi została tam nawet nagrodzona przez Polską

5 W latach dwudziestych i trzydziestych XX wieku mianem „Bücherstunde” określano wiele programów radiowych w Niemczech poświęconych literaturze. Do najbardziej znanych należała „Bücherstunde” prowadzona w latach 1927-1931 przez Leonarda Langheinricha w Funk-Stunde AG w Berlinie (FST Berlin). W 1933 roku Döblin, socjalista pochodzenia żydowskiego, musiał opuścić hitlerowskie Niemcy. W 1936 roku, krótko przed napisaniem artykułu o książce Wittlina, wysłuchał „Bücherstunde” najprawdopodobniej w Paryżu na falach nieokreślonej przez autora jednej z rozgłośni Trzeciej Rzeszy.

${ }^{6}$ Niemieckie wydawnictwo emigracyjne.

7 K. Mann, Mephisto. Roman einer Karriere, Amsterdam 1936.

819 czerwca 1936 roku „Pariser Tageszeitung” określiło powieść Mefisto mianem powieści z kluczem. E. Spangenberg, Karriere eines Romans. „Mephisto”, Klaus Mann und Gustaf Gründgens, München 1982, s. 89.

9 Wydawnictwo dla niemieckich publikacji emigracyjnych z siedzibą w Amsterdamie.

${ }^{10}$ J. Roth, Beichte eines Mörders, erzählt in einer Nacht, Amsterdam 1936. Tytuł wydania polskiego: Spowiedź mordercy. Opowiedziana w jedna noc.

11 M. Brod, Annerl, Amsterdam 1937.

12 J. Witllin, Das Salz der Erde, Amsterdam 1937.

13 Sól ziemi miała stanowić pierwszy tom trylogii Powieści o cierpliwym piechurze. Dalszymi częściami miały być: Zdrowa śmierć i Dziura w niebie. Cykl jednak nigdy się nie ukazał. Większość gotowych fragmentów drugiej części (Zdrowa śmierć) zaginęła podczas drugiej wojny światowej, gdy pisarz podjął nieudaną próbę ucieczki z Francji do Wielkiej Brytanii w 1940 roku. W 1972 roku w paryskiej „Kulturze” ukazał się jedyny ocalały urywek Zdrowej śmierci. 
Akademię Literatury ${ }^{14}$, rodzaj towarzystwa literackiego podobnego do Towarzystwa Goncourta ${ }^{15}$. Komisja nagradzająca podała w uzasadnieniu: „Książka ta szlachetność uczucia, troskę o sprawy ludzkie łączy z niezwykłą starannością formy" ${ }^{16}$. Czyta się to z uczuciem zazdrości: najwyraźniej są jeszcze kraje, gdzie o dziełach można wyrażać uznanie publicznie, co więcej: nawet nagradzać za szlachetność poglądów, troskę o ludzkie sprawy. Cóż za pokrzepiające kryteria.

Książka liczy 383 stron, nie bez racji miała w Polsce wyśmienitą prasę (... ${ }^{17}$. Czytelnik z niemieckiego kręgu kulturowego od pierwszych stron oddycha „słowiańskim” powietrzem, które po pięćdziesięciu stronach kojarzy mu się z Chtopami Władysława Reymonta ${ }^{18}$, z wielce rozległa „powieścią o czterech porach roku”, od której Wittlin zasadniczo jednak się odróżnia. Treść tego pierwszego tomu jest opowiedziana w jednym zdaniu: „Huculski dróżnik stacji Topory-Czernielica w momencie wybuchu wojny (prawie chciałbym powiedzieć w momencie nadejścia wojny) zostaje powołany do służby i pierwsze dni szkolenia spędza w węgierskim garnizonie". To wszystko. Nie dzieją się przy tym żadne dramatyczne sceny, nie dochodzi do żadnych konfliktów: ktoś zostaje powołany i wyszkolony w garnizonie do celów wojennych.

Ten tragarz i dróżnik ma charakterystyczne nazwisko: Piotr Niewiadomski, czyli: Piotr Nieznany ${ }^{19}$. Mamy przed sobą „nieznanego żołnierza”. Poważne, bardzo poważne stwierdzenie ${ }^{20}$. Przychodzi na myśl $\mathrm{Na}$ Zachodzie bez $z_{m i a n}{ }^{21}$, ale i tam znów jest widoczna olbrzymia różnica między dziełem niemieckiego i polskiego autora. Niemiecki twórca poprzestaje na jednym tomie i napełnia go mniej lub bardziej zajmującymi, mniej lub bardziej plastycznymi, ekscytującymi scenami. Słowianin ma więcej przestrzeni i trzyma się z dala od spraw ekscytujących czy przerażających. Nie dopuszcza nawet śladu „działania”. „Ktos” działa i „coś” zawsze się dzieje, ale trwa wojna, która się skończy, bez ustalenia, kto jej tak naprawdę chciał, a ludzie są powoływani

${ }^{14}$ W 1936 roku Wittlin otrzymał nagrodę „Wiadomości Literackich”, dwa lata później nagrodę Złotego Wawrzynu Polskiej Akademii Literatury.

15 Towarzystwo Goncourta - Towarzystwo Literackie (Société littéraire des Goncourt) powstałe w 1902 roku, przyznawało ono Nagrodę Goncourta (Prix Goncourt) - francuską nagrodę literacką ku czci Edmonda de Goncourta; po raz pierwszy wręczona 21 grudnia 1903 roku, przyznawana do dziś.

${ }^{16}$ E. Wiegandt, Wstęp [w:] J. Wittlin, Sól ziemi, oprac. E. Wiegandt, Wrocław 1991, s. LXXIX.

17 Druga część zdania jest niezrozumiała. Słowo „Tagesroman” nie istnieje w języku niemieckim. Być może powstał błąd w druku i chodzi tu o sformułowanie: „zarówno w prasie codziennej, jak i literackiej”.

${ }^{18}$ W tekście Döblina w tym miejscu jako imię Reymonta podane Stanisław [przyp. red.].

19 Döblin stosuje tu grę słów: „Niewiadomski”, czyli „niewiadomy”, po niemiecku także „nieznany” (unbekannt).

20 Vorwurf użyte w tekście oryginału dosłownie oznacza w języku niemieckim „zarzut”. Prawdopodobnie Döblin rozumiał przez to słowo „śmiałą ideę”.

21 E.M. Remarque, Im Westen nichts Neues, Berlin 1929. 
i maltretowani przez urzędy, ludzie, którzy są dokładnie tacy sami, jak wszyscy: całkowicie pozbawieni heroizmu, zupełnie wyniszczeni, niespokojni: oburzeni, wystraszeni, w wielu prywatnych powiązaniach. Tak, istnieją tylko prywatne powiązania i wszyscy są osobami prywatnymi, które błądzą jako masa i pojawiają się jako „armia”, od starego cesarza, który też raz tu występuje, aż do powoływanych do wojska kandydatów rabinatu.

Czy to nie jednostronność, niebezpieczne kołtuństwo, przeżytek indywidualizmu? Żyjemy przecież, patrzę w kalendarz, w czasie kolektywizmu. Co tak naprawdę często skrywa się - tchórzliwie i obłudnie - za słowem „kolektywizm"? Biurokracja, rzeczowość cesarskiego dworu, schematyzm, rządza władzy, ludzka nienawiść. Jest kolektywizm obłudny, ponad ludźmi i prawdziwy - między nimi. O tym ostatnim tylko wtedy jest mowa, gdy pozostawi ludzi samych sobie. I tak jest w przypadku Józefa Wittlina.

Jak Wittlin buduje swoją „powieść” tam, gdzie tylko przebiega (lub rozpoczyna się) „wojna”?22 (Nieznającym literatury polskiej chcę zwrócić uwagę, że przez wykształconych Polaków Wittlin był do tej pory znany przede wszystkim jako tłumacz Homera ${ }^{23}$ ). Otóż opowiada: przedstawia na stacji kolejowej kolejno sytuację Piotra Niewiadomskiego, następnie mówi, kto jest naczelnikiem stacji, kim jest siostra Piotra („syn niewiadomego ojca”24), z kim łączy go relacja, która nie jest dla niego wystarczająco dobra i wartościowa. Następnie Wittlin mówi o podróży rekrutów koleją (bardzo fachowo) i o poprzedzającym ją zebraniu na dworcu, potem pojawia się sierżant sztabowy (długi wspaniały szkic), podpułkownik inwalida. Prawdą jest to, na co w uzasadnieniu zwróciła uwagę Komisja przyznająca nagrodę: „niezwykła staranność formy" ${ }^{25}$ - chociaż generalnie w dużym stopniu tylko czas przesuwa się do przodu, a rzeczy, portrety, opisy sytuacji, działania masowe są umieszczone tylko - jedno po drugim - bez związku między sobą. Gdzie w tym znajduje się ta „powieść”? Cóż, w pewnym sensie, w znaczeniu Balzaka czy Gustava Frey$\operatorname{taga}^{26}$ lub Wassermanna ${ }^{27}$ to nie jest „powieść”, [bo - M.A.N.] nie ma żadnej tezy ani konfliktu, które by rządziły biegiem wydarzeń. Ale bieg wydarzeń sam w sobie jest tematem, nieskomplikowane, „nieprzetworzone”, otwarte na krótko spojrzenie, rzucone przez kogoś, komu bliska jest „troska o sprawy ludzkie”. Rzadki temat - to nawet nie jest „temat”, a raczej rodzaj epickości. Ta „troska o sprawy ludzkie” od razu otwiera autorowi szerszą perspektywę powieściopisarską i nie pozwala mu zagubić się w „konfliktach”.

22 Zdanie w oryginale niejasne: „Wo so nur »der Krieg« abläuft (oder beginnt), wie macht denn Wittlin seinen »Roman«?".

${ }^{23}$ Wittlin przełożył na język polski Odyseję w 1924 roku (drugi przekład ukazał się w 1931 roku, a trzeci w 1957 roku).

${ }^{24}$ Pozostaję przy określeniu ze Wstępu [w:] J. Wittlin, dz. cyt., s. LVII.

25 Zob. przypis 14.

${ }^{26}$ Gustav Freytag, 1816-1895, niemiecki powieściopisarz i dramaturg.

${ }^{27}$ Jakob Wassermann, 1873-1934, niemiecki pisarz pochodzenia żydowskiego. 
Tutaj wyczuwa się też napięcie, o którym mówiłem we wcześniejszych pracach teoretycznych. Nie przeskakuje ono z jednego miejsca w inne w ramach zainscenizowanej akcji (jak we właściwej „powieści”), lecz tkwi w każdej postaci i w każdym opisie.

Ta książka nie obciąża czytelnika żadną z aktualnych ideologii. Autor poprzestaje na „trosce o [zwykłe - M.A.N.] sprawy ludzkie”. Naturalny, piękny, cywilny, nieheroiczny związek. Książka przeciw frazesom, antyteatralna. „Człowiek spokojnie przemawiający w kraju”"28. Wydaje się, że trylogia Powieść o cierpliwym piechurze będzie polską paralelą do czeskiego Szwejka ${ }^{29}$.

${ }^{28}$ W Niemczech pojęcie historyczne (Die Stillen im Lande), nawiązujące do psalmu 35, oznaczające grupę osób skupionych wokół Gerharda Tersteegena (1697-1769), ewangelickiego mistyka i pisarza. Współcześnie często oznacza kogoś, kto pozostaje w tle, ale jego opinie odgrywają znaczącą rolę na niemieckiej scenie intelektualnej. W czasach Trzeciej Rzeszy mianem tym określano grupę chrześcijańskich pisarzy pozostających w cichej opozycji do Hitlera.

${ }^{29}$ J. Hašek, Dobrý voják Švejk a jiné podivné historky, Praha 1912. 